\title{
Extracellular Vesicles: New Players in Lymphomas
}

\author{
Victor Navarro-Tableros ${ }^{1}$, Yonathan Gomez ${ }^{2}$, Giovanni Camussi ${ }^{2}$ and Maria Felice Brizzi ${ }^{2, *}$ \\ 1 2i3T Società per la gestione dell'incubatore di imprese e per il trasferimento tecnologico Scarl, University of \\ Turin, Turin 10126, Italy; victor.navarro@2i3t.it \\ 2 Department of Medical Sciences, University of Turin, Turin 10126, Italy; yonathan.gomez@unito.it (Y.G.); \\ giovanni.camussi@unito.it (G.C.) \\ * Correspondence: mariafelice.brizzi@unito.it; Tel.: +011-670-6653
}

Received: 29 November 2018; Accepted: 18 December 2018; Published: 21 December 2018

\begin{abstract}
Lymphomas are heterogeneous diseases, and the term includes a number of histological subtypes that are characterized by different clinical behavior and molecular phenotypes. Valuable information on the presence of lymphoma cell-derived extracellular vesicles (LCEVs) in the bloodstream of patients suffering from this hematological cancer has recently been provided. In particular, it has been reported that the number and phenotype of LCEVs can both change as the disease progresses, as well as after treatment. Moreover, the role that LCEVs play in driving tumor immune escape has been reported. This makes LCEVs potential novel clinical tools for diagnosis, disease progression, and chemoresistance. LCEVs express surface markers and convey specific molecules in accordance with their cell of origin, which can be used as targets and thus lead to the development of specific therapeutics. This may be particularly relevant since circulating LCEVs are known to save lymphoma cells from anti-cluster of differentiation (CD)20-induced complement-dependent cytotoxicity. Therefore, effort should be directed toward investigating the feasibility of using LCEVs as predictive biomarkers of disease progression and/or response to treatment that can be translated to clinical use. The use of liquid biopsies in combination with serum EV quantification and cargo analysis have been also considered as potential approaches that can be pursued in the future. Upcoming research will also focus on the identification of specific molecular targets in order to generate vaccines and/or antibodies against LCEVs. Finally, the removal of circulating LCEVs has been proposed as a simple and non-invasive treatment approach. We herein provide an overview of the role of LCEVs in lymphoma diagnosis, immune tolerance, and drug resistance. In addition, alternative protocols that utilize LCEVs as therapeutic targets are discussed.
\end{abstract}

Keywords: lymphoma; extracellular vesicles; immunomodulation; innovative therapies

\section{Introduction}

Lymphomas are a group of hematopoietic-derived cancers that develop from lymphocytes. The name specifically refers to the cancerous subtypes rather than to a single disease. Several lymphoma subtypes are recognized and belong to two main groups: Hodgkin lymphoma (HL), and non-Hodgkin lymphoma (NHL). HL is a rare malignancy, with an incidence of about 2.4 per 100,000 per year, and is divided into nodular lymphocyte-predominant HL (5\%) and classical HL (95\%). Nodular lymphocyte $\mathrm{HL}$ is further subdivided into nodular lymphocyte-predominant HL, nodular sclerosis classical HL, mixed cellularity classical HL, lymphocyte-rich classical HL, and lymphocyte-depleted classical HL [1]. NHL counts for $90 \%$ of all lymphomas [2]. Common NHLs affect children, adolescents, and young adults of up to 30 years of age (CAYA). NHLs in the CAYA population include lymphoblastic diseases such as acute lymphoblastic leukemia/lymphoma and ALL/LL, which originate from immature B or $\mathrm{T}$ cells, and Burkitt lymphoma (BL), diffuse large B-cell lymphoma (DLBCL), and anaplastic large cell 
lymphoma (ALCL), which originate from mature peripheral lymphocytes [3]. The most frequent NHLs are follicular lymphomas (FL) and DLBCL (70\%). The histological transformation of FL to aggressive lymphoma occurs in $35 \%$ of patients and is associated with poor outcomes [4].

Six defined hallmarks allow cells to survive, proliferate, and disseminate in hematologic cancers, just as in solid tumors. These include: (1) sustained proliferative signals, (2) growth suppressor evasion, (3) replicative immortality, (4) invasion, (5) angiogenesis, and (6) resistance to cell death [5]. The acquisition of such features depends on the development of cancer cell genomic instability, immune system-driven inflammation, the reprogramming of tumor cellular energy metabolism, and tumor evasion from immune surveillance [5].

Growing amounts of evidence point to extracellular vesicles (EVs) functioning as pivotal mediators of cell-cell communication among both neighboring and distant cells in physiological and pathological settings, including hematological malignancies [6,7]. EV-specific deoxyribonucleic acids (DNA), lipids, distinct ribonucleic acids (RNA) repertoires, and proteins have been observed to change in response to different circumstances [8]. More importantly, EV cargoes profoundly differ in untransformed and transformed cells [9]. Moreover, EVs contribute to the signaling networks in the tumor microenvironment (TME) and promote tumor progression, immune escape, and chemoresistance [10]. Finally, EV cargo and their surface markers, which are parent-cell specific, are known to provide insight into tumor identity, making them valuable surrogate biomarkers [11].

Relevant data on the role of lymphoma cell-derived extracellular vesicles (LCEVs) in lymphoma diagnosis, immune escape, and chemoresistance will be discussed in this review. Moreover, an update on the exploitation of LCEVs as therapeutic targets will be provided.

\section{EV Biogenesis}

Exosomes and microvesicles are highly heterogeneous particles that originate from distinct subcellular compartments. They present a range of sizes and have diverse molecular composition. They have been classified into three main groups: (1) microvesicles (MVs), which are also referred to as ectosomes, shedding vesicles, or microparticles, and are formed by the outward budding of plasma membranes and present diameters ranging from 100 to $1000 \mathrm{~nm}$; (2) exosomes, which are formed inside multivesicular bodies (MVBs) via the intraluminal budding of the endosomal membrane and are smaller than MVs, with diameters ranging from 30 to $100 \mathrm{~nm}$; (3) apoptotic bodies (ABs) are large clumps of material (1000-5000 nm) that originate from cells undergoing apoptosis [12,13]. MVs and exosomes have recently been collectively defined as extracellular vesicles (EVs) [14], and this term will be used throughout this review to describe both MVs and exosomes.

EVs are important mediators of cell-cell communication that play key roles in both normal and disease processes, including cancer development and progression $[15,16]$. EVs contain cell-type specific cargo, including RNAs, DNA, and proteins, which are selectively sorted [17].

The mechanisms that are involved in EV biogenesis are not yet fully clear. However, it is generally accepted that the endosomal sorting complex required for transport (ESCRT)-dependent and ESCRT-independent signals play a crucial role in this process [17]. Once released, EVs induce a variety of signals to recipient cells [18]. After release, EVs are taken up by target cells. The mechanisms for EV uptake mainly include direct membrane fusion [19], ligand-receptor interactions [20], and phagocytosis [21], as well as clathrin-dependent [22] and clathrin-independent [23] endocytosis. EVs then release their cargo into recipient cells and induce a number of biological functions [24].

EV composition closely reflects their biogenesis and the environmental conditions of the cell of origin, and includes portions of cytosol and membrane-associated materials [25]. EV membranes are enriched in gangliosides and transferrin receptors [26], as well as cholesterol, ceramide, and sphingomyelin [27]. Furthermore, they contain several endosome-specific proteins, including cluster of differentiation (CD)9, CD63, CD81, tumor susceptibility 101 (Tsg101), and ALG-2-interacting protein $X$ (Alix). EV release depends on calcium influx, cytoskeleton reorganization, and the redistribution of phospholipids in the plasma membrane [28,29]. 
EV composition in the physiological setting largely depends on the cell type from which they originate. They transfer information and induce the reprograming of target cells in a specific manner [30,31]. EVs transport non-coding RNA species, including RNA transcripts that overlap with protein coding regions, repeat sequences, structural RNA, transference RNA (tRNA) fragments, vault RNA, small non-coding RNA (Y RNA), and small interfering RNA, as well as other small molecules [32,33]. Besides RNAs, the presence of nucleic acids, such as mitochondrial DNA (mtDNA) [34], single-stranded DNA (ssDNA) [35], and genomic double-stranded DNA (dsDNA) [36] has been described. Although the mechanism involved in EV DNA trafficking is not clear, the transfer of packaged genomic sequences that are released into the cytoplasm after nuclear-envelope breakdown during mitosis has been postulated [37].

\section{LCEVs and LME}

The molecular content of tumor-derived EVs includes a broad variety of proteins, lipids, glycans, and RNA species, and partly resembles the content of their parental cell (Figure 1) [38,39]. Furthermore, tumor-derived EVs may contain immunoinhibitory ligands and immunostimulatory molecules $[40,41]$. Malignant transformation is associated with increased EV release [38,42,43]. Moreover, cancer and lymphoma cells produce a large number of EVs that also contain molecules, driving the apoptosis of activated tumor-specific T cells, and thus impairing their cytolytic activity $[38,39,44]$. Overall, tumor-derived EVs differ from "healthy" cell-derived EVs in their functional and structural properties, as well as in their molecular profile [38,45]. Indeed, their phenotype depends on the stage and grade of malignancy $[38,46]$. There are increasing amounts of evidence to indicate that tumor-derived EVs preferentially target tumor cells rather than cells that are contained in normal tissues [47]. However, the precise mechanisms of interaction and affinity between tumor-derived EVs and target cells are still a matter of study.

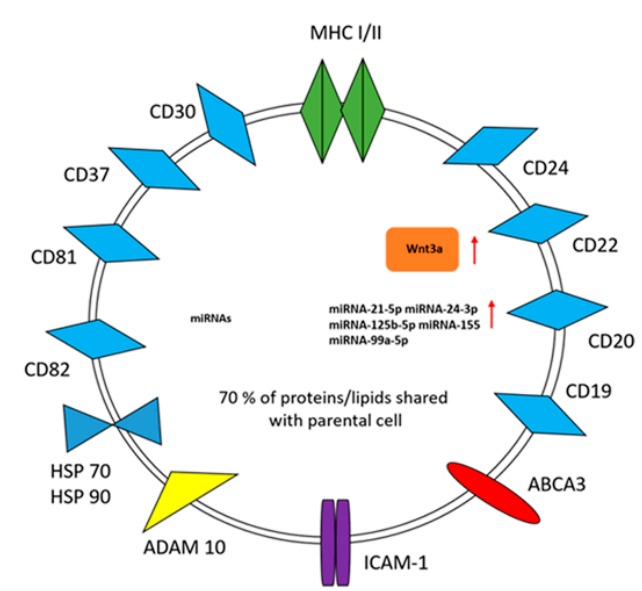

Figure 1. Lymphoma cell-derived extracellular vesicle (LCEV) cargo. LCEVs may contain nucleic acids, proteins, and lipids that resemble the content of their parental cell. The LCEV surface membrane is enriched with proteins that are involved in antigen presentation, signal transduction, adhesion, and drug resistance. Major histocompatibility complex (MHC) class I and II (MHC I/II); miRNA: micro-ribonucleic acid; ABCA3: ATP-binding cassette transporter A3; ICAM-1: Intercellular Adhesion Molecule 1; ADAM10: A Disintegrin and Metalloproteinase Domain-containing protein 10; HSP 70/90: Heat shock protein 70 and 90. Wnt3a: Wingless 3a. Red arrows indicate up-regulated molecules.

The presence of genomic DNA inside tumor cell-derived EVs has been also reported [48]. The majority of DNA is double-stranded genomic DNA, resembling that of the cell of origin, and includes mutated and amplified oncogenes as well as transposable elements $[35,36,38]$ (Figure 1). The function of this EV-DNA cargo is still unclear. 
The importance of EVs in hematological malignancies is, in part, attributed to their role in driving the hypercoagulability state, changing the tumor microenvironment and inducing tumor evasion and chemoresistance [49].

The lymphoma microenvironment (LME) participates in lymphoma by promoting tumor cell proliferation, resistance to cell death, and evasion from growth suppressors, and provides immune escape mechanisms [4]. The LME has been increasingly recognized as a dynamic and interactive system that also supports and guides drug resistance [4]. Key factors that influence LME composition include lymphoma subtypes and signaling interactions between lymphoma cells and the cells contained within the LME. A deeper knowledge of the interaction between lymphoma cells and their non-malignant microenvironment is thought to be critical to the identification of the mechanisms involved in lymphoma initiation/development and new therapeutic targets [50].

The LME consists of immune cells, stromal cells, cytokines, blood vessels, and extracellular matrix components, just as the TME. Moreover, EVs have more recently been considered to be relevant LME components [39] (Figure 2). LME composition (Table 1) is dynamic and mainly guided by cancer cells. Moreover, a bidirectional flux of information between LCEVs and EVs that are derived from LME components has been reported to influence LME composition and tumor cell features [51]. Indeed, Hansen et al. [52] have demonstrated that LCEVs that are enriched in CD30 are released into the LME and take part in the recruitment of microenvironment resident cells. More recently, it has also been reported that lymphoma B cell-derived EVs that contain mutated Myeloid differentiation primary response 88 (MYD88) are involved in bone marrow LME reprogramming [53].

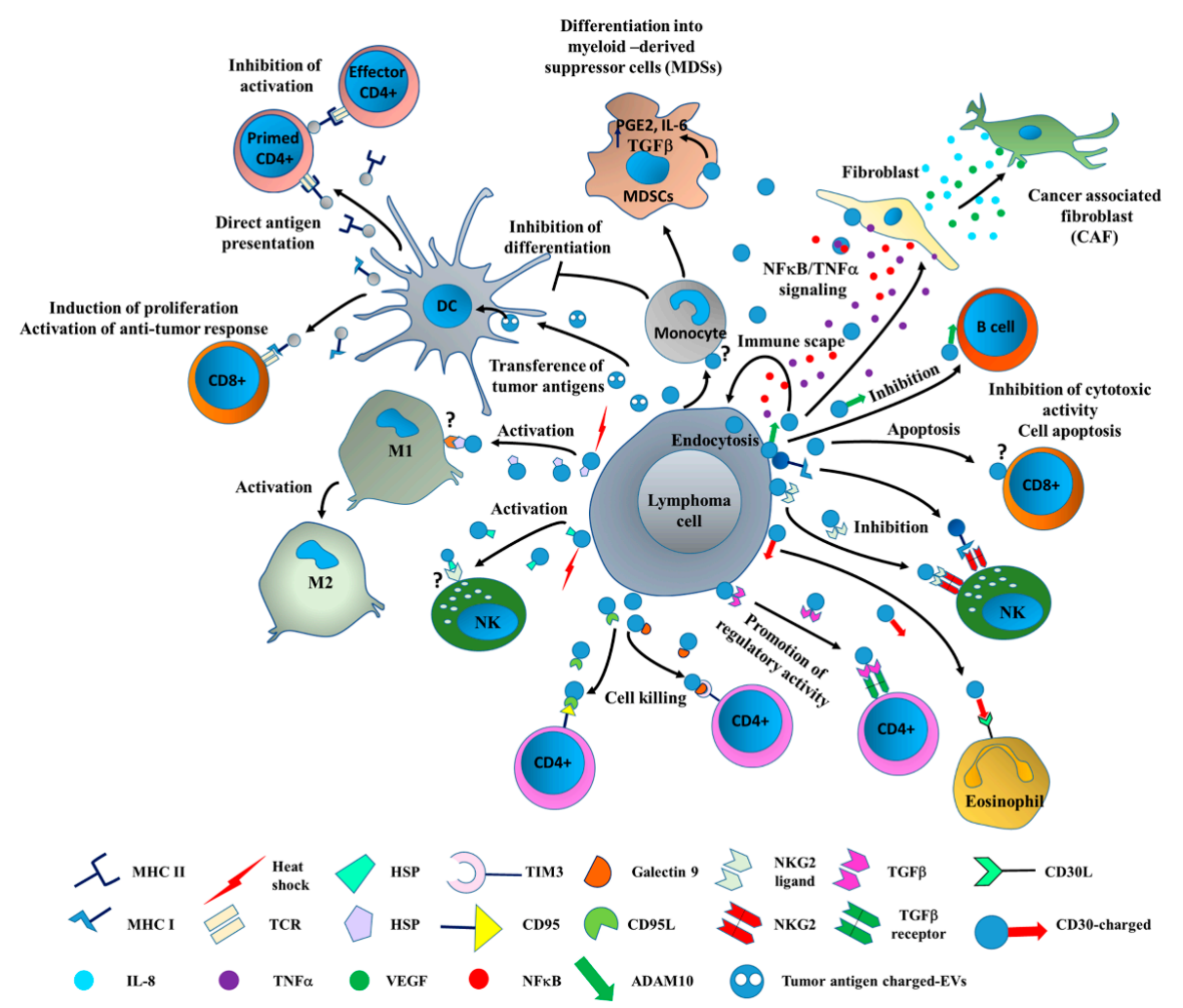

Figure 2. Cellular interaction in the lymphoma microenvironment (LME) driving immune escape. LCEVs contribute to tumor immune escape by coordinating the activation (black arrows) and/or inactivation ( $\mathrm{T}$ bars) of different cells types in the tumor niche. LCEVs express different surface markers (cluster of differentiation: CD) and transport typical components resembling their cell of origin (lymphoma cell). Key molecules enriched in LCEVs interact with receptors expressed by target cells and activate intracellular signals that differentially modulate the activity of immune cells. The activation of DCs and fibroblasts further promote EV release and EV-mediated signaling events in neighboring cells. DC: Dendritic cells; NK: Natural killer cells. 
Table 1. Lymphoma Microenvironment (LME) composition.

\begin{tabular}{cc}
\hline LME-Associated Composition & Cell Types \\
\hline \multirow{3}{*}{ Immune cells } & Cytotoxic T cells (CTLs) \\
& Follicular B helper T cells (TFH) \\
& Regulatory T cells (Treg) \\
& Natural Killer cells (NK) \\
& Bystander B cells \\
\hline Stromal cells & Mesenchymal stromal cells (MSCs) \\
& Lymphoma associated macrophages (LAMs) \\
& Myeloid-derived suppressor cells (MDSCs) \\
& Dendritic cells \\
\hline \multirow{2}{*}{ Extracellular components } & Extracellular matrix (ECM) \\
& Cytokines /Chemokines \\
& Lymphoma exosome \\
\hline
\end{tabular}

\section{Immune Regulation by Tumor-Derived EVs}

The immune response is made up of innate and adaptive immunity. The innate response depends on antigen-presenting cells (APCs), such as macrophages and dendritic cells (DCs), and natural killer cells (NK). The adaptive response relies on specific $B$ and $T$ lymphocyte activation and the generation of memory $\mathrm{T}$ cells. $\mathrm{T}$ cells are highly specialized cells that not only coordinate (T-helper: $\mathrm{Th}$ ) and suppress (T-regulatory: Treg) the immune response, but also destroy infected cells (T-cytotoxic: CTL). Furthermore, B cells secrete antibodies that mark infected cells and pathogens in order to promote their removal from circulation $[54,55]$.

Tumor cells, besides being characterized by unrestrained cell proliferation, possess powerful defensive mechanisms that allow them to escape immune surveillance and confer them with chemoresistance. Although EVs can display stimulatory or tolerogenic properties, depending on their packaged cargo, tumor-derived EVs mainly induce cues that collectively suppress the immune attack against tumors [56]. However, it has been shown that tumor-derived EVs are able to transfer tumor antigens to DCs by means of their major histocompatibility complex (MHC) class I expression, which, in turn, induces a CD8+ T cell-dependent antitumor immune response [57]. In order to escape immune surveillance and prepare a "niche" for newly generated and dispersed tumor cells, two main strategies are generally adopted by tumor cells: (1) the production of immune suppressive cytokines, and (2) the loss of target antigens to avoid their recognition by immune cells [58]. As a matter of fact, tumor-derived EVs deliver surface signals that modulate the expression of immunoregulatory genes, such as cyclooxygenase 2 (COX2), interleukin (IL)-10, CD39, CD73, programmed death-ligand (PDL)-1, and CD26, which suppress regulatory T cells (Treg cells) [59]. Additionally, tumor-derived EVs can promote the production of prostaglandin E2 (PGE2), IL-6, and tumor growth factor $\beta$ (TGF- $\beta$ ) from myeloid-derived suppressor cells (MDSC) [60]. CD8+ and CD4+ T lymphocytes are also differentially modulated by circulating tumor-derived EVs. In fact, while they inhibit CD8+ activation and proliferation, they have no effect on $\mathrm{CD} 4+\mathrm{T}$ cells. Additionally, tumor-derived EVs induce apoptosis in CD8+ T cells and enhance CD4+T regulatory cell suppressor activity [61]. EV immunoregulatory effects are not limited to T and B cells, but also involve NK cells. In fact, tumor-derived EVs are known to repress NK activity via a mechanism that involves the interaction of the MHC class I-related chain (MIC) with the natural killer group 2D receptor (NKG2D) [62]. In particular, tumor-derived EVs considerably reduce the cytotoxic activity of circulating NK and generate an immunoprivileged environment that facilitates tumor escape by downregulating NKG2D [63].

Therefore, tumor-derived EVs use the above strategies to potentiate the immunosuppressive microenvironment and favor tumor growth by: (1) reprograming macrophages toward a M2 tumor-supportive phenotype [64,65]; (2) inducing cytotoxic CD8+ T cell apoptosis [64], thus lowering NK proliferation; and (3) shifting CD4+ cells to T regulatory lymphocytes [66]. 


\section{EV-Mediated Lymphoma Immune Escape}

Immune cells have distinct roles in lymphoma progression. They induce both immunosuppressive and antitumor immune responses. Lymphoma cells play an important role in directing tumor immune escape by creating a feasible tumor microenvironment. A number of strategies are adopted by the cells to obtain this goal: (1) the direct recruitment of immune cells [67]; (2) the indirect "education" of normal cells to release a specific pattern of cytokines or chemokines [68-70]; and (3) the reprogramming of resident fibroblasts to cancer-associated fibroblasts (CAF) [71]. It is known that Treg cells exert immune-suppressive activity on lymphoma-infiltrating cytotoxic T cells, resulting in ineffective immune clearance [72]. This mechanism is secondary to the recruitment, proliferation, and differentiation of naive $\mathrm{CD} 4+\mathrm{T}$ cells, which is induced by chemokines and the growth factors that are secreted by the cells and/or by the LME components [4].

The study of tumor-derived EVs and their role in disease progression is currently one of the most attractive topics across cancer research, including that on lymphomas [39]. Despite the amount of data generated in recent years, further effort is still required if a detailed characterization of the structural and functional diversity of LCEVs and their role in immune escape mechanisms is to be achieved. LCEVs transport more than $70 \%$ of the proteins derived from their parental cells [40]. As a matter of fact, LCEVs contain discrete sets of proteins that are involved in antigen presentation, signal transduction, and cell adhesion. LCEVs also carry tumor antigens and MHC I, and are loaded with tumor surface molecules, such as CD19, CD20, and CD22, which may participate in the important signaling pathways that are involved in cell-to-cell communication in LME [40] (Figure 3). Higuchi et al. [73] have demonstrated that Epstein-Barr virus (EBV)-associated lymphomas secrete LCEVs that are mainly incorporated into monocytes/macrophages and support tumor evasion by inducing the immune regulatory phenotype in macrophages. Additionally, Ahmed et al. [74] have demonstrated that EBV infection in B cells may induce T-cell depression via LCEV-mediated apoptosis. Immune and non-immune mechanisms have been described [74]. LCEV-dependent cell-to-cell communication between distant lymphoma cells also involves educational mechanisms that are driven by CD30+ LCEVs. This mainly includes bidirectional cross-talk between malignant cells and resident fibroblasts [71]. Recent data have demonstrated that HL cells release LCEVs that express the full-length CD30 receptor and can locally modify the LME via interactions between their ligands $(\mathrm{CD} 30 \mathrm{~L}+)$ and neighboring cells. Moreover, bidirectional CD30-CD30L+ signals have been reported to contribute to the education of distant immune cells [52].

NK cells, and in particular their germline-encoded receptor NKG2D, have also been shown to play a role in NK-mediated immunosurveillance in lymphoma [75]. NKG2D is an activating molecule that recognizes self-molecules that are induced by stress [76]. Cancer cells overexpress NKG2D, and this translates into the upregulation of its ligands and more efficient NKG2D-dependent NK-mediated cell killing $[77,78]$. However, it has been reported that the downregulation of NKG2D-L is a common feature in LME, and is a relevant tumor-escape mechanism, as it suppresses NKG2D-dependent cytotoxicity [78]. Moreover, LCEVs that are enriched in NKG2D ligands also contribute to immune escape by decreasing the number of NKG2D-positive T cells [79]. 


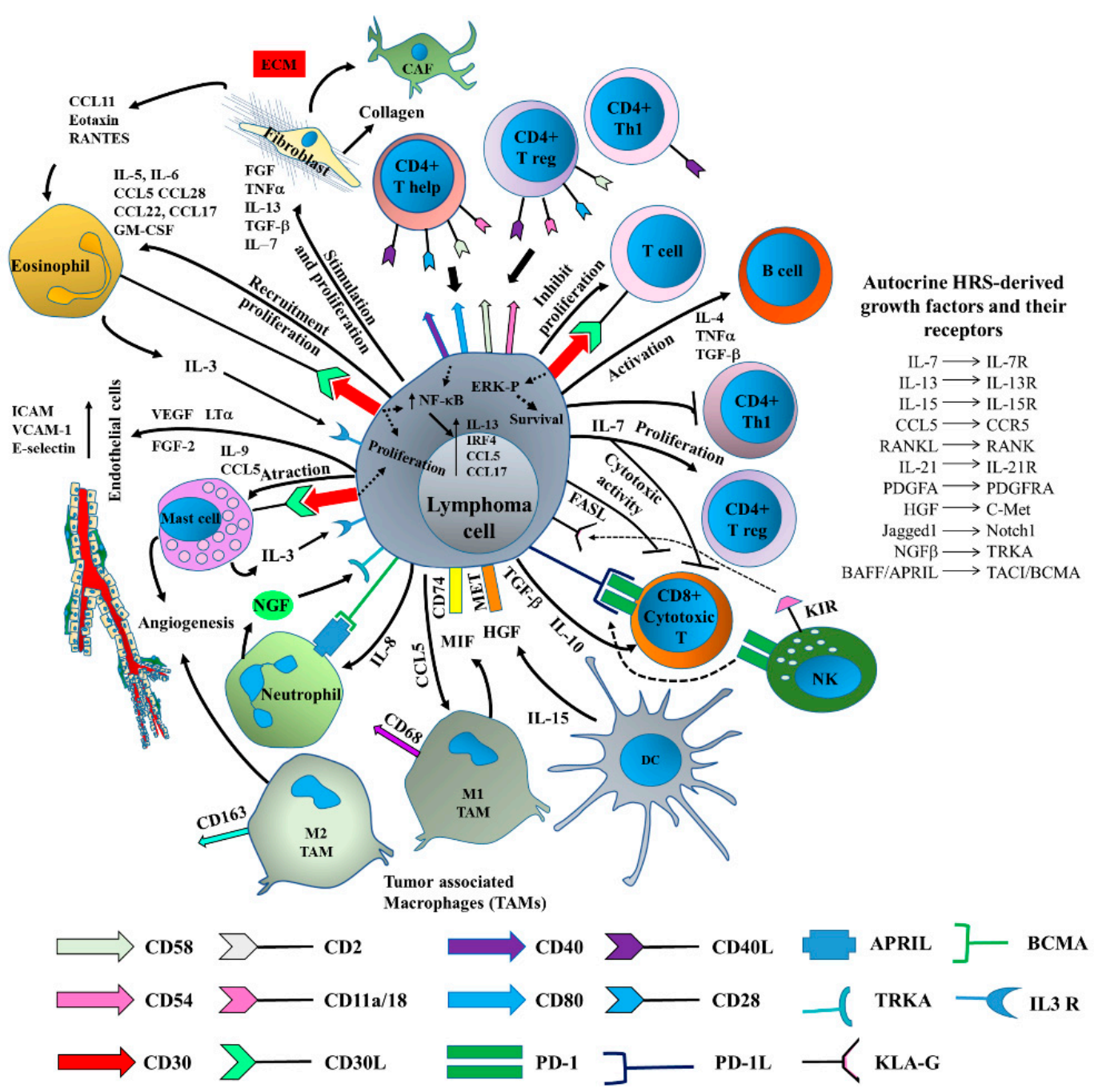

Figure 3. Bidirectional interaction between lymphoma cells and LME components involved in tumor immune escape. Lymphoma cells avoid the immune attack by three main mechanisms: (1) direct interaction with immune cells through surface molecules, (2) production of immune suppressive cytokines, and (3) loss of target antigens. Lymphoma cells also releases molecules that promote tumor growth and stimulate new vessel formation. Dotted lines correspond to shared receptors. Arrows indicate a direct effect. $\mathrm{T}$ bars indicate the inhibitory activity.

Interference with $\mathrm{T}$ cell homing that prevents the systemic antitumor immune response has been associated with the overexpression of endothelin B on tumor endothelial cells in solid tumors [80]. Further studies should be performed to investigate the possibility that such a mechanism is also present in LME.

\section{LCEVs and Angiogenesis}

Increased angiogenesis has been detected in the bone marrow of patients with hematologic disorders, including lymphomas [81]. Angiogenesis is required for tumor development, growth, and invasion. The process is regulated directly and indirectly by malignant cells using a variety of pro-angiogenic and anti-angiogenic mediators, including: (1) miRNAs; (2) proteins; (3) lipids; and (4) transcription factors [82].

Tumor-derived EVs also promote angiogenesis by inducing stroma cells to release several pro-angiopoietic factors [83]. More recently, it has been shown that tumor-derived endothelial cells directly act on neighboring cells via EV-mediated miRNA transfer [84]. LCEVs that express Heat 
Shock Protein 70 kilodaltons (HSP-70), myelocytomatosis cancergene (c-Myc), B-cell lymphoma 2 (Bcl-2), myeloid cell leukemia sequence 1 (Mcl-1), X-linked inhibitor of apoptosis protein (xIAP), B-cell lymphoma-extra-large (Bcl-xL), and other molecules, such as phosphatidylinositol, Extracellular signal-Regulated Kinases (ERK), Mitogen-Activated Protein Kinases (MAPK), chemokines, cell surface receptors, and $G$ proteins also act on angiogenesis [85]. Indeed, LCEVs that are released in LME actively participate in the angiogenic processes by delivering mRNA, miRNAs, and angiogenic proteins, including Vascular Endothelial Growth Factor (VEGF) [86].

\section{Liquid Biopsy as a New EV-Based Screening Method}

Solid biopsy is the gold standard for the diagnosis of a variety of diseases, particularly cancers. However, tumors that cannot be surgically treated and/or present limited accessibility are a major limitation of solid biopsies. Liquid biopsies have recently been proposed as a means to supplement surgical biopsy and resolve its limitations [87].

A "liquid biopsy" is a minimally invasive blood test that provides a consistent non-invasive clinical tool for the molecular profiling of cancer patients [87]. This approach may allow tumor cells, tumor DNA, miRNAs, and tumor-derived EVs to be identified in circulation. Moreover, liquid biopsies are currently being used to obtain more accurate diagnoses, identify specific biomarkers, and monitor disease progression, clonal evolution, and the response to treatment [88]. Accordingly, liquid biopsies have been proposed as an alternative diagnostic method for the screening of new biomarkers in LCEVs that may be translated to the clinic.

\section{LCEVs as Markers of Disease and Progression}

HL and NHL cells express more than 1000 membrane proteins, including 178 protein clusters. HL and NHL specific markers have been proposed as new molecular candidates for differential diagnosis between HL and NHLs [89]. HL cell lines and tumor tissues from HL patients express a number of proteins that are involved in immune response. Additionally, the enrichment of activated leukocyte cell adhesion molecule (ALCAM), cathepsin S, CD26, CD44, interleukin 1 receptor 2 (IL1R2), macrophage migration inhibitory factor (MIF), and thymus and activation regulated chemokine (TARC) in the plasma of HL patients has been correlated with lymphoma progression [90]. CD81+ and CD63+ LCEVs are particularly enriched in CD19, CD20, CD24, CD37, and HLA-DR [91]. The number of specific LCEVs and their surface markers also correlate with lymphoma subtypes. For example, LCEVs isolated from NHL patients are enriched in CD19 and CD20, while EVs isolated from patients with HL are enriched in CD30 [92]. In particular, CD20+ LCEVs are considered the best biomarkers for disease progression and antibody-based treatment response, as their circulating level directly correlates to the CD20+ circulating cells in patients [93]. Sera from HL patients also contain a high number of CD30+ LCEVs [92], which has been correlated with patient outcomes [94]. Therefore, CD30+ LCEVs, besides representing a valuable diagnostic marker, might also be used to monitor responses to treatment [95]. Likewise, Tosetti et al. [96] have demonstrated that LCEVs released by HL cells are enriched in the mature bioactive form of ADAM10. In addition, Jones et al. [97] have demonstrated that miRNA-21 and miRNA-155 are enriched in the sera of HL patients. Accordingly, a standardized size-exclusion chromatography (SEC) analysis has demonstrated the presence of more than 400 miRNAs in the highly enriched populations of HL patient-derived LCEVs. miRNA-21, miRNA-155, miRNA-21-5p, miRNA-24-3p, miRNA-127-3p, and let7a-5 are found among them [97]. A large Spanish multicentric study has recently demonstrated the feasibility of monitoring cancer evolution by measuring B-cell lymphoma $6(B C L-6)$ and C-MYC mRNA levels in LCEVs isolated from the plasma of patients with B-cell lymphomas. The study also demonstrated that both markers are predictors of worse progression-free survival (PFS). Moreover, it has been shown that LCEV C-MYC mRNA content may also predict poor prognosis and/or incomplete treatment response [98]. The relevance of LCEVs as potential predictors of drug efficacy has also been demonstrated in patients with diffuse DLBCL. The observation that two miRNAs (miRNA-99a-5p and miRNA-125b-5p) were 
enriched in DLBCL EVs was found to correlate with shorter progression-free survival and drug resistance [99]. Finally, a direct correlation between circulating LCEV number, disease progression, and response to treatment has been reported [38]. These observations support the notion that LCEVs can be considered not only as potential markers of disease and disease progression, but also as biomarkers to monitor response to treatment.

\section{LCEVs as Mediators of Drug Resistance}

The identification of a suitable B-cell target antigen, CD20, in the early 1980s paved the way for the development of monoclonal antibody technology, and in particular promoted an immunological therapeutic approach to NHL patient treatment [100]. CD20 is a membrane-spanning phosphoprotein that is expressed by late pre-B and mature B cells, as well as by the majority of NHL B cells. The absence of this marker on early B-cell progenitors and immature cells facilitated the development of a specific antibody-based therapy that can recognize human CD20 and induce complement-dependent (CDC) and antibody-dependent cellular cytotoxicity (ADCC) [101]. Rituximab was the first anti-cancer biological drug to be approved as an anti-CD20 antibody (RTX; Rituxan ${ }^{\circledR}$, MabThera ${ }^{\circledR}$ ) by the United States (US) Food and Drug Administration in 1997 [102].

The last decade has seen a new anti-CD20-based therapy for lymphoma treatment being developed and approved [103]. Unfortunately, it is becoming evident that B-cell lymphoma cells release CD20+ LCEVs. It has been suggested that circulating CD20+ LCEVs capture rituximab, and thus hamper its therapeutic effect. This seems to be particularly relevant at the beginning of treatment. In particular, it has been demonstrated that the high number of circulating CD20+ LCEVs can "sequestrate" rituximab, reducing the effective number of deposable molecules, and in turn, reducing its therapeutic effectiveness [104]. Moreover, it has been reported that LCEVs efficiently extrude drugs and can drive drug resistance in aggressive B-cell lymphomas via the ATP-transporter A3-mediated mechanism (ABCA3) [105]. The expression of HSP-70, c-Myc, Bcl-2, Mcl-1, xIAP, and Bcl-xL and other molecules, such as phosphatidylinositol, ERK, MAPK, chemokines, cell surface receptors, and G proteins in LCEVs has also been associated with resistance against humoral immunotherapy [85]. Moreover, the increase in ADAM10 activity that is mediated by LCEVs has been reported to interfere with immunotherapeutic approaches. The release of Tumor Necrosis Factor (TNF) $\alpha$, soluble MHC I polypeptide-related sequence A (sMICA), and soluble CD30 (sCD30) has been reported as a crucial mechanism [96]. This observation has led to specific ADAM10 blockers being proposed to boost the anti-lymphoma immune response and/or drive efficient antibody-drug-conjugate (ADC)-based and Ab immunotherapy [96].

\section{EV-Based Lymphoma Therapies}

Tumor-derived EVs are involved in cancer development on multiple levels. It is worth noting that EVs also drive "adaptation/defense" and chemoresistance mechanisms [106]. This has spurred current research toward feasible approaches that can interfere with the formation/release or spread of tumor-derived EVs. Researchers are currently focusing on four main areas: (1) EV-based vaccines; (2) the development of specific antibodies to neutralize tumor-derived EVs; (3) the targeting of EV biogenesis; and (4) the extracorporeal removal of tumor-derived EVs (Figure 4). 


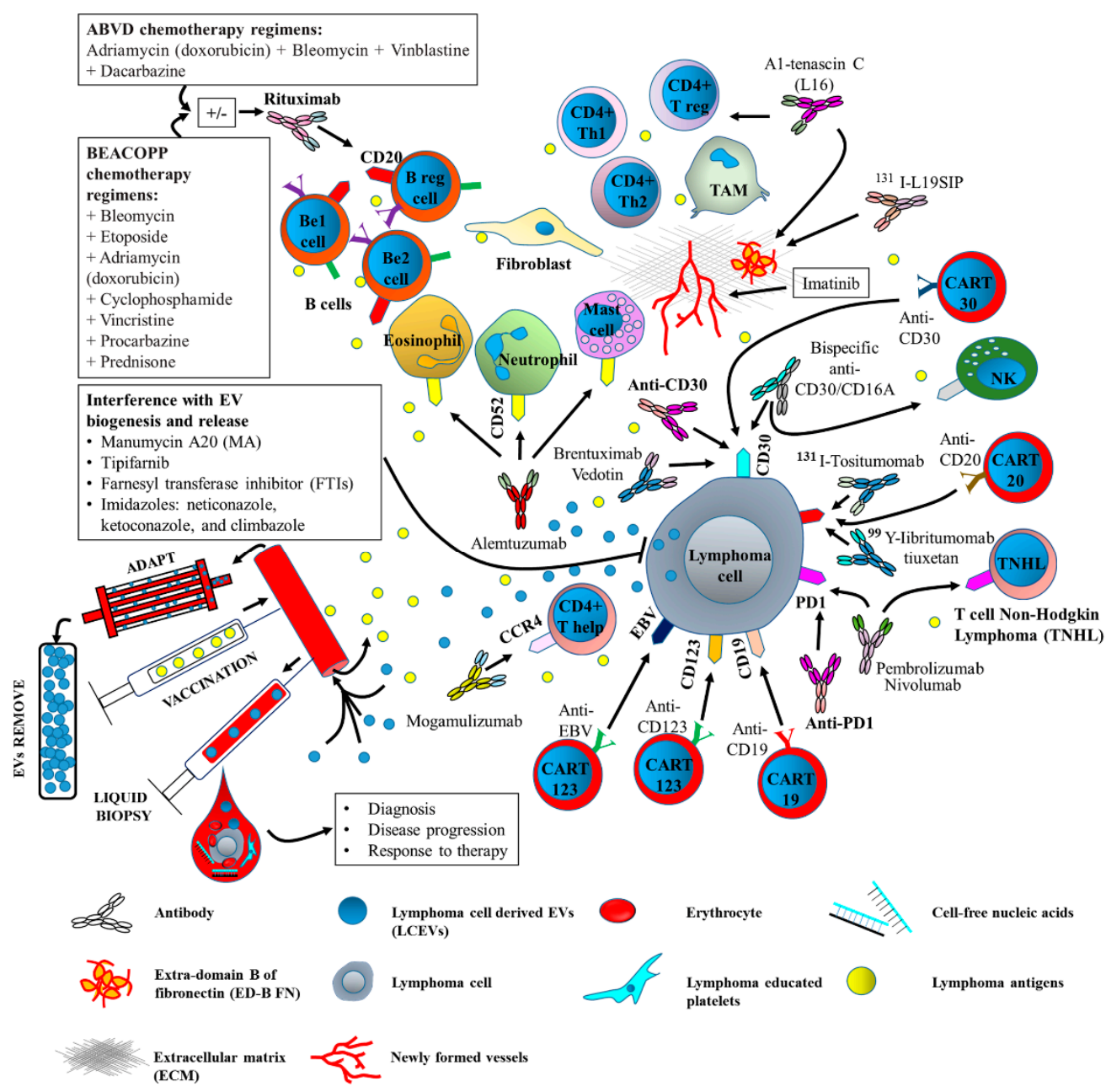

Figure 4. Scheme of therapeutic approaches (currently used or under investigation) and liquid biopsy using LCEVs. Oncogenic drugs and specific antibodies targeting surface molecules expressed by LME components represent the main therapeutic approaches used in clinic. Current clinical trials are also evaluating new potential approaches using vaccinations with tumor antigens. ADAPT represents a potential approach to remove LCEVs from the bloodstream. Liquid biopsy has been proposed as screening method for diagnosis, disease progress, and response to therapy. New potential approaches are represented by the chimeric antigen receptor (CAR), which is introduced in immune cells to retarget their cytotoxicity toward specific tumor antigens (CART). CARs are synthetic proteins generated by the fusion of a single chain variable fragment $(\mathrm{scFv})$ derived from a monoclonal antibody with the signaling and costimulatory machinery of the T-cell receptor (TCR) [107]. CART cells have been evaluated as promising new cell-based therapy approach using CD19 [108], CD30, CD123 [109], and the Epstein-Barr virus protein (EBV) as molecular targets [110]. ADAPT: Adaptive dynamic artificial poly-ligand targeting.

\subsection{EV-Based Vaccines}

Cancer vaccines are considered a class of therapeutics and are also called biologic response modifiers (BRM) [111]. Single or combined tumor antigens are injected to drive immunoprotection [112]. The identification of selective antigens that are abundantly expressed on cancer cells has set the basis for the design of a number of cancer vaccine trials [113]. However, there are few data to demonstrate the feasibility of monitoring the immune response, meaning that vaccination is not yet considered a feasible therapeutic approach for lymphoma [114]. 
The heterogeneity of the molecular profile of tumor cells during progression and after treatment is considered the most relevant limitation of vaccination-based cancer therapy. Moreover, antigen-specific T-cell repertoire diversities, and the presence or absence of pre-existing immune tolerance, have also contributed to unsuccessful responses to vaccine-based therapy [115].

It has been reported that HL-derived LCEVs are able to induce a potent and specific cytotoxic response in CD8+ T lymphocytes. This effect relies on the upregulation of MHC molecules, costimulatory molecules, and cytokines by LCEV-mediated DC functional maturation [85]. DCs, which are the most proficient APCs, can take up tumor antigens and, depending on environmental cues, present antigens at tumor sites and lymphoid organs to either prime, sustain, or abrogate EV-based active vaccination [116]. Menay et al. [117] have demonstrated that T-cell lymphoma-derived LCEVs are able to induce an efficient immune response and memory against lymphoma. This effect was associated with T helper 1-mediated responses. However, Chen et al. [85] have more recently demonstrated the presence of a dual LCEV-mediated effect. They showed that LCEVs may display immunosuppressive activity that can promote in vivo tumor growth. On the other hand, they also demonstrated that $\mathrm{T}$ cells, which were recovered from tumor-bearing mice treated with LCEVs, displayed increased anti-lymphoma activity. This effect relies on DC-mediated T-cell expansion and the inhibition of Th2 immunosuppressive activity [85]. These data suggest that the education of DCs using LCEVs as tumor-associated antigens may be a novel DC-based immunotherapy [85].

More recently, the combined use of standard-of-care chemotherapeutics and EV-based vaccines has been proposed as a means to modulate immunity in solid tumors. For example, cyclophosphamide has been shown to amplify the cytotoxic T-cell response against cancers when combined with DC-derived EVs [118,119]. Future effort should be devoted to an evaluation of the effectiveness of this combined approach as an alternative treatment in lymphomas as well.

\subsection{Neutralizing EV-Based Approaches}

Although rituximab has been shown to improve the overall survival of patients with both aggressive and indolent B-cell NHL [120], remission is only achieved in 50\% of CD20-positive lymphoma patients [120]. This indicates that additional and more specific antibodies are required. CD19, CD22, CD37, and CD40 have been identified, thanks to lymphoma molecular profiling [89], and are currently under investigation for the development of new antibody-based treatments. A number of new specific antibodies, including the anti-CD22 [121], anti-CD40 [122], anti-CD19 [123], anti-CD19/CD3 [124], and anti-CD37 antibodies [125], are currently used for alternative antibody-based therapy in lymphomas. Since these markers [40] are also expressed by LCEVs, these approaches, if validated, could also be used to remove LCEVs from circulation. Therefore, a dual effect may be sought.

\subsection{Targeting EV Biogenesis}

The blockade of EV release from tumor cells has been proposed as an alternative EV-mediated therapeutic approach in cancer [126]. The identification of key cellular pathways that are involved in EV biogenesis would be crucial to this purpose. It has been demonstrated that EBV infection modulates EV biogenesis and the miRNA content in Burkit lymphoma cells [127]. However, the complex biological process of EV trafficking and the large number of proteins involved represent a significant challenge.

Despite the enormous amount of effort that has been made to identify the signaling pathways involved in LCEV formation and release, few data are currently available. Koch et al. [105] have recently shown that LCEV biogenesis is strictly dependent on ATP Binding Cassette Subfamily A Member 3 (ABCA3) expression, and that genetic ablation and chemical interference with ABCA3 expression improve drug accumulation in the nucleus of B-cell lymphomas.

The inhibition of sphingolipid ceramide formation via a range of approaches has also been shown to interfere with intra-endosomal membrane transport and EV generation $[17,128]$. Several imidazoles (neticonazole, ketoconazole, and climbazole) as well as manumycin A20 (MA) and tipifarnib, which are 
two farnesyl transferase inhibitors (FTIs), have been found to inhibit the specific pathways that are involved in EV biogenesis in cancer cells [129].

The Rab family is known to control vesicular trafficking, including its motility, docking, budding, and the fusion of numerous vesicular transport intermediates [130]. More importantly, the enrichment of Rab35 on EVs has been shown to play a crucial role in the regulation of vesicle density [131]. Ostrowsky et al. [132] have demonstrated that several Rab family members are also involved in EV biogenesis and provide noticeable results, which strengthens the concept of using Rab27 inhibitors to interfere with EV biogenesis.

The role of intracellular $\mathrm{Ca}^{2+}$ concentration has also been reported to contribute to EV biogenesis in erythroleukemia cell lines. This was observed using dimethyl amiloride (DMA), which is an inhibitor of $\mathrm{Na}^{+} / \mathrm{H}^{+}$and $\mathrm{Na}^{+} / \mathrm{Ca}^{2+}$ exchangers. In particular, it has been shown that DMA is able to decrease constitutive and $\mathrm{Ca}^{2+}$-dependent $\mathrm{EV}$ release [133]. DMA was also found to reduce the secretion of LCEVs in mice that bear lymphomas. This translates into the inhibition of myeloid-cell suppressor functions and an improvement in immune surveillance [134].

\subsection{Extracorporeal Removal of LCEVS}

EV dialysis has been proposed as a novel approach for the removal of EVs in cancer and lymphoma patients [135]. However, no solid data on EV removal by hemofiltration are yet available. Nevertheless, Aethlon Medical has proposed a therapeutic hemofiltration approach, termed the Aethlon ADAPTTM (adaptive dialysis-like affinity platform technology) system, which consists of immobilized affinity agents in the outer-capillary space of hollow-fiber plasma separator cartridges integrated with either a standard dialysis unit or with devices approved for continuous renal replacement therapy (CRRT) [135]. So far, the combination of this technology with dialysis has been applied to virus reduction/clearance in hepatitis C-infected patients. Feasibility was indirectly supported by a reduction in the number of infected cells [135]. Therefore, its potential application in LCEV removal still requires validation, despite this approach being a valuable innovative option.

\section{Conclusions}

EVs have been increasingly considered simple and accurate non-invasive biomarkers in many cancers [11]. In particular, LCEVs have been investigated as novel "multiomic shells" for disease detection, immune escape, response to treatment, and drug resistance. Moreover, the cross-talk that occurs between malignant cells, immune cells, and other LME components via LCEVs has gained particular attention for its role as a driver of lymphoma progression and treatment response [6]. Recently, it has been reported that circulating EVs that bear programmed death-ligand 1 (PD-L1) change during treatment, due to specific immune responses [136]. This suggests that LCEVs could be used as real-time biomarkers for treatment response [137]. Moreover, the use of LCEVs as biomarkers of treatment response would be particularly relevant for patient management during treatment, as the International Prognostic Index (IPI) predicts survival time, but not treatment efficacy [138]. Furthermore, most lymphoma-associated antigens being expressed on LCEVs has led to the proposal of the possibility of using them for immune approaches [38]. This is further supported by the finding that LCEVs carry a large number of proteins that can be considered potential target candidates [40]. Effort has also been focused on the identification of the mechanisms that regulate LCEV biogenesis. This would allow the development of novel therapeutic approaches in which the targeting of LCEVs might interfere with tumor growth. This would also be particularly relevant if interfering agents could be directed to CD20+ LCEVs, which are known to act as decoy targets to facilitate tumor escape from humoral immunotherapy [139]. However, a refined and detailed understanding of LCEV actions is still required if advanced therapeutic options are to be successfully developed. Moreover, an in-depth investigation of the relationship between LCEVs, disease aggressiveness, and recurrence would also provide assistance. These topics must be addressed before the LCEV field can be translated to the clinic. 
Author Contributions: V.N.-T.: Manuscript writing and Figure preparation; Y.G.: contributed to manuscript writing and Figure preparation; G.C.: Manuscript editing; M.F.B.: Manuscript writing and editing.

Funding: This work has been supported by grants obtained by G.C. and M.F.B. from the Associazione Italiana per la Ricerca sul Cancro (AIRC) projects IG 2015.16973 and IG 2015.17630 and by grants obtained by MFB from Ministero dell'Istruzione, Università e Ricerca (MIUR) ex 60\%.

Acknowledgments: Special thanks to Heimary Barreto for her helpful advises in graphics.

Conflicts of Interest: The Authors declare no conflict of interest.

\section{References}

1. Lynch, R.C.; Gratzinger, D.; Advani, R.H. Clinical Impact of the 2016 Update to the WHO Lymphoma Classification. Curr. Treat. Options Oncol. 2017. [CrossRef] [PubMed]

2. Swerdlow, S.H.; Campo, E.; Pileri, S.A.; Harris, N.L.; Stein, H.; Siebert, R.; Advani, R.; Ghielmini, M.; Salles, G.A.; Zelenetz, A.D.; et al. The 2016 revision to the World Health Organization (WHO) classification of lymphoid neoplasms. Blood 2016. [CrossRef] [PubMed]

3. Galardy, P.J.; Bedekovics, T.; Hermiston, M.L. Targeting childhood, adolescent and young adult non-Hodgkin lymphoma: Therapeutic horizons. Br. J. Haematol. 2016. [CrossRef] [PubMed]

4. Tarte, K. Role of the microenvironment across histological subtypes of NHL. Hematology 2017. [CrossRef]

5. Hanahan, D.; Weinberg, R.A. Hallmarks of cancer: The next generation. Cell 2011. [CrossRef] [PubMed]

6. Boyiadzis, M.; Whiteside, T.L. The emerging roles of tumor-derived exosomes in hematological malignancies. Leukemia 2017. [CrossRef] [PubMed]

7. Tetta, C.; Ghigo, E.; Silengo, L.; Deregibus, M.C.; Camussi, G. Extracellular vesicles as an emerging mechanism of cell-to-cell communication. Endocrine 2013. [CrossRef] [PubMed]

8. Bebelman, M.P.; Smit, M.J.; Pegtel, D.M.; Baglio, S.R. Biogenesis and function of extracellular vesicles in cancer. Pharmacol. Ther. 2018. [CrossRef] [PubMed]

9. Roy, S.; Hochberg, F.H.; Jones, P.S. Extracellular vesicles: The growth as diagnostics and therapeutics; a survey. J. Extracell. Vesicles 2018. [CrossRef]

10. Rackov, G.; Garcia-Romero, N.; Esteban-Rubio, S.; Carrión-Navarro, J.; Belda-Iniesta, C.; Ayuso-Sacido, A. Vesicle-mediated control of cell function: The role of extracellular matrix and microenvironment. Front. Physiol. 2018. [CrossRef]

11. Ko, J.; Carpenter, E.; Issadore, D. Detection and isolation of circulating exosomes and microvesicles for cancer monitoring and diagnostics using micro-/nano-based devices. Analyst 2016. [CrossRef] [PubMed]

12. Ohno, S.I.; Drummen, G.P.C.; Kuroda, M. Focus on extracellular vesicles: Development of extracellular vesicle-based therapeutic systems. Int. J. Mol. Sci. 2016, 17, 172. [CrossRef] [PubMed]

13. Abels, E.R.; Breakefield, X.O. Introduction to Extracellular Vesicles: Biogenesis, RNA Cargo Selection, Content, Release, and Uptake. Cell Mol. Neurobiol. 2016. [CrossRef] [PubMed]

14. Lötvall, J.; Hill, A.F.; Hochberg, F.; Buzás, E.I.; Vizio, D.D.; Gardiner, C.; Gho, Y.S.; Kurochkin, I.V.; Mathivanan, S.; Quesenberry, P.; et al. Minimal experimental requirements for definition of extracellular vesicles and their functions: A position statement from the International Society for Extracellular Vesicles. J. Extracell. Vesicles 2014. [CrossRef] [PubMed]

15. Hurwitz, S.N.; Conlon, M.M.; Rider, M.A.; Brownstein, N.C.; Meckes, D.G. Nanoparticle analysis sheds budding insights into genetic drivers of extracellular vesicle biogenesis. J. Extracell. Vesicles 2016. [CrossRef] [PubMed]

16. Malloci, M.; Perdomo, L.; Veerasamy, M.; Andriantsitohai, R.; Simard, G.; Martınez, M.C. Extracellular Vesicles: Mechanisms in Human Health and Disease. Antioxid. Redox Signal. 2018. [CrossRef] [PubMed]

17. Trajkovic, K.; Hsu, C.; Chiantia, S.; Rajendran, L.; Wenzel, D.; Wieland, F.; Schwille, P.; Brügger, B.; Simons, M. Ceramide Triggers Budding of Exosome Vesicles into Multivesicular Endosomes. Science 2008. [CrossRef]

18. Ratajczak, M.Z.; Ratajczak, D.; Pedziwiatr, D. Extracellular microvesicles (ExMVs) in cell to cell communication: A role of telocytes. Adv. Exp. Med. Biol. 2016. [CrossRef]

19. Tian, T.; Wang, Y.; Wang, H.; Zhu, Z.; Xiao, Z. Visualizing of the cellular uptake and intracellular trafficking of exosomes by live-cell microscopy. J. Cell. Biochem. 2010. [CrossRef]

20. Miyanishi, M.; Tada, K.; Koike, M.; Uchiyama, Y.; Kitamura, T.; Nagata, S. Identification of Tim4 as a phosphatidylserine receptor. Nature 2007. [CrossRef] 
21. Feng, D.; Zhao, W.L.; Ye, Y.Y.; Bai, X.C.; Liu, R.Q.; Chang, L.F.; Zhou, Q.; Sui, S.F. Cellular internalization of exosomes occurs through phagocytosis. Traffic 2010. [CrossRef] [PubMed]

22. Tian, T.; Zhu, Y.L.; Zhou, Y.Y.; Liang, G.F.; Wang, Y.Y.; Hu, F.H.; Xiao, Z.D. Exosome uptake through clathrin-mediated endocytosis and macropinocytosis and mediating miR-21 delivery. J. Biol. Chem. 2014. [CrossRef] [PubMed]

23. Damke, H.; Baba, T.; Van Der Bliek, A.M.; Schmid, S.L. Clathrin-independent pinocytosis is induced in cells overexpressing a temperature-sensitive mutant of dynamin. J. Cell Biol. 1995. [CrossRef]

24. Greening, D.W.; Simpson, R.J. Understanding extracellular vesicle diversity-Current status. Expert Rev. Proteom. 2018. [CrossRef] [PubMed]

25. Yáñez-Mó, M.; Siljander, P.R.M.; Andreu, Z.; Zavec, A.B.; Borràs, F.E.; Buzas, E.I.; Buzas, K.; Casal, E.; Cappello, F.; Carvalho, J.; et al. Biological properties of extracellular vesicles and their physiological functions. J. Extracell. Vesicles 2015. [CrossRef] [PubMed]

26. Tan, S.S.; Yin, Y.; Lee, T.; Lai, R.C.; Yeo, R.W.Y.; Zhang, B.; Choo, A.; Lim, S.K. Therapeutic MSC exosomes are derived from lipid raft microdomains in the plasma membrane. J. Extracell. Vesicles 2013. [CrossRef] [PubMed]

27. Subra, C.; Laulagnier, K.; Perret, B.; Record, M. Exosome lipidomics unravels lipid sorting at the level of multivesicular bodies. Biochimie 2007. [CrossRef]

28. Cocucci, E.; Racchetti, G.; Meldolesi, J. Shedding microvesicles: Artefacts no more. Trends Cell Biol. 2009. [CrossRef]

29. Tetta, C.; Bruno, S.; Fonsato, V.; Deregibus, M.C.; Giovanni, C. The role of microvesicles in tissue repair. Organogenesis 2011. [CrossRef]

30. Ciardiello, C.; Cavallini, L.; Spinelli, C.; Yang, J.; Reis-Sobreiro, M.; De Candia, P.; Minciacchi, V.R.; Di Vizio, D. Focus on extracellular vesicles: New frontiers of cell-to-cell communication in cancer. Int. J. Mol. Sci. 2016, 17, 175. [CrossRef]

31. Zhang, J.; Li, S.; Li, L.; Li, M.; Guo, C.; Yao, J.; Mi, S. Exosome and exosomal microRNA: Trafficking, sorting, and function. Genom. Proteomics Bioinform. 2015. [CrossRef] [PubMed]

32. Nolte'T Hoen, E.N.M.; Buermans, H.P.J.; Waasdorp, M.; Stoorvogel, W.; Wauben, M.H.M.; 'T Hoen, P.A.C. Deep sequencing of RNA from immune cell-derived vesicles uncovers the selective incorporation of small non-coding RNA biotypes with potential regulatory functions. Nucleic Acids Res. 2012. [CrossRef] [PubMed]

33. Urbanelli, L.; Magini, A.; Buratta, S.; Brozzi, A.; Sagini, K.; Polchi, A.; Tancini, B.; Emiliani, C. Signaling pathways in exosomes biogenesis, secretion and fate. Genes 2013, 4, 152. [CrossRef] [PubMed]

34. Guescini, M.; Genedani, S.; Stocchi, V.; Agnati, L.F. Astrocytes and Glioblastoma cells release exosomes carrying mtDNA. J. Neural Transm. 2010. [CrossRef] [PubMed]

35. Balaj, L.; Lessard, R.; Dai, L.; Cho, Y.J.; Pomeroy, S.L.; Breakefield, X.O.; Skog, J. Tumour microvesicles contain retrotransposon elements and amplified oncogene sequences. Nat. Commun. 2011. [CrossRef] [PubMed]

36. Thakur, B.K.; Zhang, H.; Becker, A.; Matei, I.; Huang, Y.; Costa-Silva, B.; Zheng, Y.; Hoshino, A.; Brazier, H.; Xiang, J.; et al. Double-stranded DNA in exosomes: A novel biomarker in cancer detection. Cell Res. 2014. [CrossRef] [PubMed]

37. Iraci, N.; Leonardi, T.; Gessler, F.; Vega, B.; Pluchino, S. Focus on extracellular vesicles: Physiological role and signalling properties of extracellular membrane vesicles. Int. J. Mol. Sci. 2016, 17, 171. [CrossRef]

38. Van Eijndhoven, M.A.J.; Zijlstra, J.M.; Groenewegen, N.J.; Drees, E.E.E.; van Niele, S.; Baglio, S.R.; Koppers-Lalic, D.; van der Voorn, H.; Libregts, S.F.W.M.; Wauben, M.H.M.; et al. Plasma vesicle miRNAs for therapy response monitoring in Hodgkin lymphoma patients. JCI Insights 2016. [CrossRef]

39. Xu, B.; Wang, T. Intimate cross-talk between cancer cells and the tumor microenvironment of B-cell lymphomas: The key role of exosomes. Tumor Biol. 2017. [CrossRef]

40. Yao, Y.; Wei, W.; Sun, J.; Chen, L.; Deng, X.; Ma, L.; Hao, S. Proteomic analysis of exosomes derived from human lymphoma cells. Eur. J. Med. Res. 2015. [CrossRef]

41. Grange, C.; Camussi, G. Immunosuppressive role of extracellular vesicles: HLA-G, an important player. Ann. Transl. Med. 2017. [CrossRef] [PubMed]

42. Yu, J.L.; May, L.; Lhotak, V.; Shahrzad, S.; Shirasawa, S.; Weitz, J.I.; Coomber, B.L.; Mackman, N.; Rak, J.W. Oncogenic events regulate tissue factor expression in colorectal cancer cells: Implications for tumor progression and angiogenesis. Blood 2005. [CrossRef] [PubMed] 
43. Lima, L.G.; Oliveira, A.S.; Campos, L.C.; Bonamino, M.; Chammas, R.; Werneck, C.C.; Vicente, C.P.; Barcinski, M.A.; Petersen, L.C.; Monteiro, R.Q. Malignant transformation in melanocytes is associated with increased production of procoagulant microvesicles. Thromb. Haemost. 2011. [CrossRef] [PubMed]

44. Valenti, R.; Huber, V.; Filipazzi, P.; Pilla, L.; Sovena, G.; Villa, A.; Corbelli, A.; Fais, S.; Parmiani, G.; Rivoltini, L. Human tumor-released microvesicles promote the differentiation of myeloid cells with transforming growth factor-beta-mediated suppressive activity on T lymphocytes. Cancer Res. 2006. [CrossRef] [PubMed]

45. Brenner, A.; Su, G.; Momen-Heravi, F. Isolation of Extracellular Vesicles for Cancer Diagnosis and Functional Studies. Methods Mol. Biol. 2019. [CrossRef]

46. Taylor, D.D.; Lyons, K.S.; Gerçel-Taylor, Ç. Shed membrane fragment-associated markers for endometrial and ovarian cancers. Gynecol. Oncol. 2002. [CrossRef] [PubMed]

47. Parolini, I.; Federici, C.; Raggi, C.; Lugini, L.; Palleschi, S.; De Milito, A.; Coscia, C.; Iessi, E.; Logozzi, M.; Molinari, A.; et al. Microenvironmental $\mathrm{pH}$ is a key factor for exosome traffic in tumor cells. J. Biol. Chem. 2009. [CrossRef]

48. Lee, T.H.; D'Asti, E.; Magnus, N.; Al-Nedawi, K.; Meehan, B.; Rak, J. Microvesicles as mediators of intercellular communication in cancer-the emerging science of cellular "debris". Semin. Immunopathol. 2011. [CrossRef]

49. Litwińska, Z.; Łuczkowska, K.; Machaliński, B. Extracellular vesicles in hematological malignancies. Leuk. Lymphoma. 2018. [CrossRef]

50. Wang, H.-W.; Balakrishna, J.P.; Pittaluga, S.; Jaffe, E.S. Diagnosis of Hodgkin lymphoma in the modern era. Br. J. Haematol. 2018. [CrossRef]

51. Kumar, D.; Xu, M.L. Microenvironment Cell Contribution to Lymphoma Immunity. Front. Oncol. 2018. [CrossRef] [PubMed]

52. Hansen, H.P.; Engels, H.M.; Dams, M.; Paes Leme, A.F.; Pauletti, B.A.; Simhadri, V.L.; Dürkop, H.; Reiners, K.S.; Barnert, S.; Engert, A.; et al. Protrusion-guided extracellular vesicles mediate CD30 trans-signalling in the microenvironment of Hodgkin's lymphoma. J. Pathol. 2014. [CrossRef]

53. Manček-Keber, M.; Lainšček, D.; Benčina, M.; Chen, J.G.; Romih, R.; Hunter, Z.R.; Treon, S.P.; Jerala, R. Extracellular vesicle-mediated transfer of constitutively active MyD88 L265P engages MyD88wt and activates signaling. Blood 2018. [CrossRef]

54. Turvey, S.E.; Broide, D.H. Innate immunity. J. Allergy Clin. Immunol. 2010. [CrossRef]

55. Bonilla, F.A.; Oettgen, H.C. Adaptive immunity. J. Allergy Clin. Immunol. 2010. [CrossRef]

56. Théry, C.; Ostrowski, M.; Segura, E. Membrane vesicles as conveyors of immune responses. Nat. Rev. Immunol. 2009. [CrossRef]

57. Wolfers, J.; Lozier, A.; Raposo, G.; Regnault, A.; Théry, C.; Masurier, C.; Flament, C.; Pouzieux, S.; Faure, F.; Tursz, T.; et al. Tumor-derived exosomes are a source of shared tumor rejection antigens for CTL cross-priming. Nat. Med. 2001. [CrossRef]

58. Czernek, L.; Düchler, M. Functions of Cancer-Derived Extracellular Vesicles in Immunosuppression. Arch. Immunol. Ther. Exp. 2017. [CrossRef] [PubMed]

59. Muller, L.; Mitsuhashi, M.; Simms, P.; Gooding, W.E.; Whiteside, T.L. Tumor-derived exosomes regulate expression of immune function-related genes in human T cell subsets. Sci. Rep. 2016. [CrossRef] [PubMed]

60. Xiang, X.; Poliakov, A.; Liu, C.; Liu, Y.; Deng, Z.B.; Wang, J.; Cheng, Z.; Shah, S.V.; Wang, G.J.; Zhang, L.; et al. Induction of myeloid-derived suppressor cells by tumor exosomes. Int. J. Cancer 2009. [CrossRef]

61. Wieckowski, E.U.; Visus, C.; Szajnik, M.; Szczepanski, M.J.; Storkus, W.J.; Whiteside, T.L. Tumor-Derived Microvesicles Promote Regulatory T Cell Expansion and Induce Apoptosis in Tumor-Reactive Activated CD8+ T Lymphocytes. J. Immunol. 2009. [CrossRef] [PubMed]

62. Bauer, S. Activation of natural killer cells and T cells by NKG2D, a receptor for stress-inducible MICA. Science 1999. [CrossRef]

63. Ashiru, O.; Boutet, P.; Fernández-Messina, L.; Agüera-González, S.; Skepper, J.N.; Valés-Gómez, M.; Reyburn, H.T. Natural killer cell cytotoxicity is suppressed by exposure to the human NKG2D ligand MICA*008 that is shed by tumor cells in exosomes. Cancer Res. 2010. [CrossRef] [PubMed]

64. De Vrij, J.; Niek Maas, S.L.; Kwappenberg, K.M.C.; Schnoor, R.; Kleijn, A.; Dekker, L.; Luider, T.M.; De Witte, L.D.; Litjens, M.; Van Strien, M.E.; et al. Glioblastoma-derived extracellular vesicles modify the phenotype of monocytic cells. Int. J. Cancer 2015. [CrossRef] [PubMed] 
65. Shinohara, H.; Kuranaga, Y.; Kumazaki, M.; Sugito, N.; Yoshikawa, Y.; Takai, T.; Taniguchi, K.; Ito, Y.; Akao, Y. Regulated Polarization of Tumor-Associated Macrophages by miR-145 via Colorectal Cancer-Derived Extracellular Vesicles. J. Immunol. 2017. [CrossRef] [PubMed]

66. Whiteside, T.L. Immune modulation of T-cell and NK (natural killer) cell activities by TEXs (tumour-derived exosomes). Biochem. Soc. Trans. 2013. [CrossRef] [PubMed]

67. Fischer, M.; Juremalm, M.; Olsson, N.; Backlin, C.; Sundström, C.; Nilsson, K.; Enblad, G.; Nilsson, G. Expression of CCL5/RANTES by Hodgkin and reed-sternberg cells and its possible role in the recruitment of mast cells into lymphomatous tissue. Int. J. Cancer 2003. [CrossRef]

68. Jundt, F.; Anagnostopoulos, I.; Bommert, K.; Emmerich, F.; Muller, G.; Foss, H.D.; Royer, H.D.; Stein, H.; Dorken, B. Hodgkin/Reed-Sternberg cells induce fibroblasts to secrete eotaxin, a potent chemoattractant for T cells and eosinophils. Blood 1999, 94, 2065-2071.

69. Skinnider, B.F.; Kapp, U.; Mak, T.W. The role of interleukin 13 in classical Hodgkin lymphoma. Leuk. Lymphoma 2002. [CrossRef]

70. Maggio, E.; van den Berg, A.; Diepstra, A.; Kluiver, J.; Visser, L.; Poppema, S. Chemokines, cytokines and their receptors in Hodgkin's lymphoma cell lines and tissues. Ann. Oncol. 2002. [CrossRef]

71. Dörsam, B.; Bösl, T.; Reiners, K.S.; Barnert, S.; Schubert, R.; Shatnyeva, O.; Zigrino, P.; Engert, A.; Hansen, H.P.; Von Strandmann, E.P. Hodgkin lymphoma-derived extracellular vesicles change the secretome of fibroblasts toward a CAF phenotype. Front. Immunol. 2018. [CrossRef] [PubMed]

72. Marshall, N.A.; Christie, L.E.; Munro, L.R.; Culligan, D.J.; Johnston, P.W.; Barker, R.N.; Vickers, M.A. Immunosuppressive regulatory $\mathrm{T}$ cells are abundant in the reactive lymphocytes of Hodgkin lymphoma. Blood 2004. [CrossRef] [PubMed]

73. Higuchi, H.; Yamakawa, N.; Imadome, K.I.; Yahata, T.; Kotaki, R.; Ogata, J.; Kakizaki, M.; Fujita, K.; Lu, J.; Yokoyama, K.; et al. Role of exosomes as a proinflammatory mediator in the development of EBV-associated lymphoma. Blood 2018. [CrossRef] [PubMed]

74. Ahmed, W.; Philip, P.S.; Attoub, S.; Khan, G. Epstein-Barr virus-infected cells release Fas ligand in exosomal fractions and induce apoptosis in recipient cells via the extrinsic pathway. J. Gen. Virol. 2015. [CrossRef] [PubMed]

75. Rosario, M.; Liu, B.; Kong, L.; Collins, L.I.; Schneider, S.E.; Chen, X.; Han, K.; Jeng, E.K.; Rhode, P.R.; Leong, J.W.; et al. The IL-15-Based ALT-803 Complex Enhances Fc $\gamma$ RIIIa-Triggered NK Cell Responses and in Vivo Clearance of B Cell Lymphomas. Clin. Cancer Res. 2016. [CrossRef] [PubMed]

76. Nausch, N.; Cerwenka, A. NKG2D ligands in tumor immunity. Oncogene 2008. [CrossRef] [PubMed]

77. Gonzalez, S.; Groh, V.; Spies, T. Immunobiology of human NKG2D and its ligands. Curr. Top. Microbiol. Immunol. 2006. [CrossRef]

78. Salih, H.R. Soluble NKG2D ligands: Prevalence, release, and functional impact. Front. Biosci. 2008. [CrossRef]

79. Clayton, A. Induction of heat shock proteins in B-cell exosomes. J. Cell Sci. 2005. [CrossRef]

80. Buckanovich, R.J.; Facciabene, A.; Kim, S.; Benencia, F.; Sasaroli, D.; Balint, K.; Katsaros, D.; O'Brien-Jenkins, A.; Gimotty, P.A.; Coukos, G. Endothelin B receptor mediates the endothelial barrier to $\mathrm{T}$ cell homing to tumors and disables immune therapy. Nat. Med. 2008. [CrossRef]

81. Aguayo, A.; Kantarjian, H.; Manshouri, T.; Gidel, C.; Estey, E.; Thomas, D.; Koller, C.; Estrov, Z.; Brien, S.O.; Keating, M.; et al. Angiogenesis in acute and chronic leukemias and myelodysplastic syndromes. Leukemia 2000, 96, 2240-2245.

82. Todorova, D.; Simoncini, S.; Lacroix, R.; Sabatier, F.; Dignat-George, F. Extracellular vesicles in angiogenesis. Circ. Res. 2017. [CrossRef] [PubMed]

83. Grange, C.; Tapparo, M.; Collino, F.; Vitillo, L.; Damasco, C.; Deregibus, M.C.; Tetta, C.; Bussolati, B.; Camussi, G. Microvesicles released from human renal cancer stem cells stimulate angiogenesis and formation of lung premetastatic niche. Cancer Res. 2011. [CrossRef] [PubMed]

84. Lombardo, G.; Gili, M.; Grange, C.; Cavallari, C.; Dentelli, P.; Togliatto, G.; Taverna, D.; Camussi, G.; Brizzi, M.F. IL-3R-alpha blockade inhibits tumor endothelial cell-derived extracellular vesicle (EV)-mediated vessel formation by targeting the $\beta$-catenin pathway. Oncogene 2018. [CrossRef] [PubMed]

85. Chen, Z.; You, L.; Wang, L.; Huang, X.; Liu, H.; Wei, J.Y.; Zhu, L.; Qian, W. Dual effect of DLBCL-derived EXOs in lymphoma to improve DC vaccine efficacy in vitro while favor tumorgenesis in vivo. J. Exp. Clin. Cancer Res. 2018. [CrossRef] 
86. Yang, J.; Li, W.; He, X.; Zhang, G.; Yue, L.; Chai, Y. VEGF overexpression is a valuable prognostic factor for non-Hodgkin's lymphoma evidence from a systemic meta-analysis. Dis. Mark. 2015. [CrossRef]

87. Mader, S.; Pantel, K. Liquid biopsy: Current status and future perspectives. Oncol. Res. Treat. 2017. [CrossRef]

88. Thompson, J.C.; Yee, S.S.; Troxel, A.B.; Savitch, S.L.; Fan, R.; Balli, D.; Lieberman, D.B.; Morrissette, J.D.; Evans, T.L.; Bauml, J.; et al. Detection of therapeutically targetable driver and resistance mutations in lung cancer patients by next-generation sequencing of cell-free circulating tumor DNA. Clin. Cancer Res. 2016. [CrossRef]

89. Hofmann, A.; Thiesler, T.; Gerrits, B.; Behnke, S.; Sobotzki, N.; Omasits, U.; Bausch-Fluck, D.; Bock, T.; Aebersold, R.; Moch, H.; et al. Surfaceome of classical Hodgkin and non-Hodgkin lymphoma. Proteomics Clin. Appl. 2015. [CrossRef]

90. Ma, Y.; Visser, L.; Roelofsen, H.; De Vries, M.; Diepstra, A.; Van Imhoff, G.; Van Der Wal, T.; Luinge, M.; Alvarez-Llamas, G.; Vos, H.; et al. Proteomics analysis of Hodgkin lymphoma: Identification of new players involved in the cross-talk between HRS cells and infiltrating lymphocytes. Blood 2008. [CrossRef]

91. Oksvold, M.P.; Kullmann, A.; Forfang, L.; Kierulf, B.; Li, M.; Brech, A.; Vlassov, A.V.; Smeland, E.B.; Neurauter, A.; Pedersen, K.W. Expression of B-Cell surface antigens in subpopulations of exosomes released from B-cell lymphoma cells. Clin. Ther. 2014. [CrossRef] [PubMed]

92. Caivano, A.; Laurenzana, I.; De Luca, L.; La Rocca, F.; Simeon, V.; Trino, S.; D'Auria, F.; Traficante, A.; Maietti, M.; Izzo, T.; et al. High serum levels of extracellular vesicles expressing malignancy-related markers are released in patients with various types of hematological neoplastic disorders. Tumor Biol. 2015. [CrossRef] [PubMed]

93. Domnikova, N.P.; Dolgikh, T.Y.; Sholenberg, E.V.; Vorontsova, E.V.; Goreva, O.B.; Mel'Nikova, E.V.; Gorbachenko, E.A.; Grishanova, A.Y. Blood microvesicles during chronic lymphoproliferative diseases. Bull. Exp. Biol. Med. 2013. [CrossRef]

94. Nadali, G.; Tavecchia, L.; Zanolin, E.; Bonfante, V.; Viviani, S.; Camerini, E.; Musto, P.; Renzo, N.D.; Carotenuto, M.; Chilosi, M.; et al. Serum Level of the Soluble Form of the CD30 Molecule Identifies Patients With Hodgkin's Disease at High Risk of Unfavorable Outcome. Blood 1998, 91, 3011-3016. [PubMed]

95. Küppers, R. New insights in the biology of Hodgkin lymphoma. Am. Soc. Hematol. 2012. [CrossRef]

96. Tosetti, F.; Venè, R.; Camodeca, C.; Nuti, E.; Rossello, A.; D’Arrigo, C.; Galante, D.; Ferrari, N.; Poggi, A.; Zocchi, M.R. Specific ADAM10 inhibitors localize in exosome-like vesicles released by Hodgkin lymphoma and stromal cells and prevent sheddase activity carried to bystander cells. Oncoimmunology 2018. [CrossRef] [PubMed]

97. Jones, K.; Nourse, J.P.; Keane, C.; Bhatnagar, A.; Gandhi, M.K. Plasma microRNA are disease response biomarkers in classical hodgkin lymphoma. Clin. Cancer Res. 2014. [CrossRef] [PubMed]

98. Provencio, M.; Rodríguez, M.; Cantos, B.; Sabín, P.; Quero, C.; García-Arroyo, F.R.; Rueda, A.; Maximiano, C.; Rodríguez-Abreu, D.; Sánchez, A.; et al. mRNA in exosomas as a liquid biopsy in non-Hodgkin Lymphoma: A multicentric study by the Spanish Lymphoma Oncology Group. Oncotarget 2017. [CrossRef]

99. Feng, Y.; Zhong, M.; Zeng, S.; Wang, L.; Liu, P.; Xiao, X.; Liu, Y. Exosome-derived miRNAs as predictive biomarkers for diffuse large B-cell lymphoma chemotherapy resistance. Epigenomics 2018. [CrossRef]

100. Saleh, M. Monoclonal antibody therapy of non-Hodgkin's lymphoma: The Rituximab story. J. Med. Assoc. Ga. 2003, 1, 39-46.

101. Engelhard, M. Anti-CD20 antibody treatment of non-Hodgkin lymphomas. Clin. Immunol. 2016. [CrossRef] [PubMed]

102. Golay, J.; Semenzato, G.; Rambaldi, A.; Foà, R.; Gaidano, G.; Gamba, E.; Pane, F.; Pinto, A.; Specchia, G.; Zaja, F.; et al. Lessons for the clinic from rituximab pharmacokinetics and pharmacodynamics. MAbs 2013. [CrossRef] [PubMed]

103. Younes, A. Beyond chemotherapy: New agents for targeted treatment of lymphoma. Nat. Rev. Clin. Oncol. 2011. [CrossRef] [PubMed]

104. Aung, T.; Chapuy, B.; Vogel, D.; Wenzel, D.; Oppermann, M.; Lahmann, M.; Weinhage, T.; Menck, K.; Hupfeld, T.; Koch, R.; et al. Exosomal evasion of humoral immunotherapy in aggressive B-cell lymphoma modulated by ATP-binding cassette transporter A3. Proc. Natl. Acad. Sci. USA 2011. [CrossRef] [PubMed]

105. Koch, R.; Aung, T.; Vogel, D.; Chapuy, B.; Wenzel, D.; Becker, S.; Sinzig, U.; Venkataramani, V.; Von Mach, T.; Jacob, R.; et al. Nuclear trapping through inhibition of exosomal export by indomethacin increases cytostatic efficacy of doxorubicin and pixantrone. Clin. Cancer Res. 2016. [CrossRef] [PubMed] 
106. Santos, J.C.; Ribeiro, M.L.; Sarian, L.O.; Ortega, M.M.; Derchain, S.F. Exosomes-mediate microRNAs transfer in breast cancer chemoresistance regulation. Am. J. Cancer Res. 2016. [CrossRef]

107. Ruella, M.; Klichinsky, M.; Kenderian, S.S.; Shestova, O.; Ziober, A.; Kraft, D.O.; Gill, S. Overcoming the Immunosuppressive Tumor Microenvironment of Hodgkin Lymphoma Using Chimeric Antigen Receptor T Cells. Cancer Discov. 2017. [CrossRef] [PubMed]

108. Filley, A.C.; Henriquez, M.; Dey, M. CART Immunotherapy: Development, Success, and Translation to Malignant Gliomas and Other Solid Tumors. Front. Oncol. 2018. [CrossRef]

109. Aoki, T.; Steidl, C. Novel Biomarker Approaches in Classic Hodgkin Lymphoma. Cancer J. 2018. [CrossRef]

110. Bröckelmann, P.J.; Borchmann, P.; Engert, A. Current and future immunotherapeutic approaches in Hodgkin lymphoma. Leuk. Lymphoma 2016. [CrossRef]

111. Stickney, D.R.; Foon, K.A. Biologic response modifiers: Therapeutic approaches to lymphoproliferative diseases. Curr. Opin. Oncol. 1992, 4, 847-855. [CrossRef] [PubMed]

112. Sheng, J.; Qin, H.; Zhang, D.; Zhang, X.; Liu, L.; Li, B. New Strategies for Therapeutic Cancer Vaccines. Anticancer Agents Med. Chem. 2018. [CrossRef] [PubMed]

113. Chu, Y.; Liu, Q.; Wei, J.; Liu, B. Personalized cancer neoantigen vaccines come of age. Theranostics 2018. [CrossRef] [PubMed]

114. Marron, T.U.; Ronner, L.; Martin, P.E.; Flowers, C.R.; Brody, J.D. Vaccine strategies for the treatment of lymphoma: Preclinical progress and clinical trial update. Immunotherapy 2016. [CrossRef] [PubMed]

115. Gilboa, E. The makings of a tumor rejection antigen. Immunity 1999. [CrossRef]

116. Viaud, S.; Théry, C.; Ploix, S.; Tursz, T.; Lapierre, V.; Lantz, O.; Zitvogel, L.; Chaput, N. Dendritic cell-derived exosomes for cancer immunotherapy: What's next? Cancer Res. 2010. [CrossRef]

117. Menay, F.; Herschlik, L.; De Toro, J.; Cocozza, F.; Tsacalian, R.; Gravisaco, M.J.; Di Sciullo, M.P.; Vendrell, A.; Waldner, C.I.; Mongini, C. Exosomes isolated from ascites of T-cell lymphoma-bearing mice expressing surface CD24 and HSP-90 induce a tumor-specific immune response. Front. Immunol. 2017. [CrossRef]

118. Chaput, N.; Taïeb, J.; Schartz, N.E.C.; André, F.; Angevin, E.; Zitvogel, L. Exosome-based immunotherapy. Cancer Immunol. Immunother. 2004. [CrossRef]

119. Taieb, J.; Chaput, N.; Schartz, N.; Roux, S.; Novault, S.; Menard, C.; Ghiringhelli, F.; Terme, M.; Carpentier, A.F.; Darrasse-Jese, G.; et al. Chemoimmunotherapy of Tumors: Cyclophosphamide Synergizes with Exosome Based Vaccines. J. Immunol. 2006. [CrossRef]

120. Salles, G.; Barrett, M.; Foà, R.; Maurer, J.; O’Brien, S.; Valente, N.; Wenger, M.; Maloney, D.G. Rituximab in B-Cell Hematologic Malignancies: A Review of 20 Years of Clinical Experience. Adv. Ther. 2017. [CrossRef]

121. Leonard, J.P.; Goldenberg, D.M. Preclinical and clinical evaluation of epratuzumab (anti-CD22 IgG) in B-cell malignancies. Oncogene 2007. [CrossRef] [PubMed]

122. Furman, R.; Forero-Torres, A.; Shustov, A.; Drachman, J. A phase I study of dacetuzumab (SGN-40, a humanized anti-CD40 monoclonal antibody) in patients with chronic lymphocytic leukemia. Leuk Lymphoma. 2010. [CrossRef] [PubMed]

123. Blanc, V.; Bousseau, A.; Caron, A.; Carrez, C.; Lutz, R.J.; Lambert, J.M. SAR3419: An anti-CD19-maytansinoid immunoconjugate for the treatment of B-cell malignancies. Clin. Cancer Res. 2011. [CrossRef] [PubMed]

124. Nagorsen, D.; Baeuerle, P.A. Immunomodulatory therapy of cancer with T cell-engaging BiTE antibody blinatumomab. Exp. Cell Res. 2011. [CrossRef] [PubMed]

125. Zhao, X.; Lapalombella, R.; Joshi, T.; Cheney, C.; Gowda, A.; Hayden-Ledbetter, M.S.; Baum, P.R.; Lin, T.S.; Jarjoura, D.; Lehman, A.; et al. Targeting CD37-positive lymphoid malignancies with a novel engineered small modular immunopharmaceutical. Blood 2007. [CrossRef]

126. Huang, M.-B.; Gonzalez, R.R.; Lillard, J.; Bond, V.C. Secretion modification region-derived peptide blocks exosome release and mediates cell cycle arrest in breast cancer cells. Oncotarget 2017. [CrossRef] [PubMed]

127. Nanbo, A.; Katano, H.; Kataoka, M.; Hoshina, S.; Sekizuka, T.; Kuroda, M.; Ohba, Y. Infection of Epstein-Barr virus in type III latency modulates biogenesis of exosomes and the expression profile of exosomal miRNAs in the Burkitt lymphoma Mutu cell lines. Cancers 2018, 10, 237. [CrossRef]

128. Menck, K.; Sönmezer, C.; Worst, T.S.; Schulz, M.; Dihazi, G.H.; Streit, F.; Erdmann, G.; Kling, S.; Boutros, M.; Binder, C.; et al. Neutral sphingomyelinases control extracellular vesicles budding from the plasma membrane. J. Extracell. Vesicles 2017. [CrossRef] 
129. Datta, A.; Kim, H.; McGee, L.; Johnson, A.E.; Talwar, S.; Marugan, J.; Southall, N.; Hu, X.; Lal, M.; Mondal, D.; et al. High-Throughput screening identified selective inhibitors of exosome biogenesis and secretion: A drug repurposing strategy for advanced cancer. Sci. Rep. 2018. [CrossRef]

130. Zerial, M.; McBride, H. Heterogeneity of Rab effectors. Nat. Rev. Mol. Cell Biol. 2001. [CrossRef]

131. Hsu, C.; Morohashi, Y.; Yoshimura, S.I.; Manrique-Hoyos, N.; Jung, S.Y.; Lauterbach, M.A.; Bakhti, M.; Grønborg, M.; Möbius, W.; Rhee, J.S.; et al. Regulation of exosome secretion by Rab35 and its GTPase-activating proteins TBC1D10A-C. J. Cell Biol. 2010. [CrossRef] [PubMed]

132. Ostrowski, M.; Carmo, N.B.; Krumeich, S.; Fanget, I.; Raposo, G.; Savina, A.; Moita, C.F.; Schauer, K.; Hume, A.N.; Freitas, R.P.; et al. Rab27a and Rab27b control different steps of the exosome secretion pathway. Nat. Cell Biol. 2010. [CrossRef] [PubMed]

133. Savina, A.; Furlán, M.; Vidal, M.; Colombo, M.I. Exosome release is regulated by a calcium-dependent mechanism in K562 cells. J. Biol. Chem. 2003. [CrossRef] [PubMed]

134. Chalmin, F.; Ladoire, S.; Mignot, G.; Vincent, J.; Bruchard, M.; Remy-Martin, J.P.; Boireau, W.; Rouleau, A.; Simon, B.; Lanneau, D.; et al. Membrane-associated Hsp72 from tumor-derived exosomes mediates STAT3-dependent immunosuppressive function of mouse and human myeloid-derived suppressor cells. J. Clin. Investig. 2010. [CrossRef] [PubMed]

135. Marleau, A.M.; Chen, C.S.; Joyce, J.A.; Tullis, R.H. Exosome removal as a therapeutic adjuvant in cancer. J. Transl. Med. 2012. [CrossRef] [PubMed]

136. Theodoraki, M.N.; Yerneni, S.S.; Hoffmann, T.K.; Gooding, W.E.; Whiteside, T.L. Clinical significance of PD-L1 exosomes in plasma of head and neck cancer patients. Clin. Cancer Res. 2018. [CrossRef] [PubMed]

137. Chen, G.; Huang, A.C.; Zhang, W.; Zhang, G.; Wu, M.; Xu, W.; Yu, Z.; Yang, J.; Wang, B.; Sun, H.; et al. Exosomal PD-L1 contributes to immunosuppression and is associated with anti-PD-1 response. Nature 2018. [CrossRef]

138. Jabbour, E.; Peslin, N.; Arnaud, P.; Ferme, C.; Carde, P.; Vantelon, J.M.; Bocaccio, C.; Bourhis, J.H.; Koscielny, S.; Ribrag, V. Prognostic value of the age-adjusted International Prognostic Index in chemosensitive recurrent or refractory non-Hodgkin's lymphomas treated with high-dose BEAM therapy and autologous stem cell transplantation. Leuk. Lymphoma 2005. [CrossRef]

139. Michot, J.M.; Lazarovici, J.; Ghez, D.; Danu, A.; Fermé, C.; Bigorgne, A.; Ribrag, V.; Marabelle, A.; Aspeslagh, S. Challenges and perspectives in the immunotherapy of Hodgkin lymphoma. Eur. J. Cancer. 2017. [CrossRef]

(C) 2018 by the authors. Licensee MDPI, Basel, Switzerland. This article is an open access article distributed under the terms and conditions of the Creative Commons Attribution (CC BY) license (http:/ / creativecommons.org/licenses/by/4.0/). 